\title{
Phytophthora Blight and Dieback in North Carolina Nurseries During a 2003 Survey
}

\author{
C. Y. Warfield, J. Hwang, and D. M. Benson, Department of Plant Pathology, North Carolina State University, \\ Raleigh 27695
}

\begin{abstract}
Warfield, C. Y., Hwang, J., and Benson, D. M. 2008. Phytophthora blight and dieback in North Carolina nurseries during a 2003 survey. Plant Dis. 92:474-481.

A survey of 14 nurseries growing hybrid rhododendron, Pieris spp., or Viburnum spp. was conducted as part of the 2003 Sudden Oak Death Pilot National Survey to determine if Phytophthora ramorum, the causal agent of sudden oak death, had been introduced to nurseries in North Carolina. Over 220,000 hybrid rhododendrons, 1,700 plants of Pieris spp., and 2,800 plants of Viburnum spp. were surveyed. Across nurseries, blight and dieback incidence averaged $2.4 \%$ for Pieris spp. and $10 \%$ for rhododendron. P. ramorum was not recovered by isolation or detected by polymerase chain reaction in the 347 plant samples collected. Three species of Phytophthora were isolated from hybrid rhododendron and Pieris spp., but no Phytophthora isolates were recovered from Viburnum spp. P. citricola and P. cambivora were isolated most frequently (61 and 39 isolates, respectively), while 2 isolates of $P$. cactorum were recovered. Occasionally, two Phytophthora spp. were found in the same block of rhododendrons within a nursery, but only one species was recovered from an individual plant. Most cultivars of rhododendron surveyed, including 'English Roseum,' 'Nova Zembla,' and 'Roseum Elegans,' had less than 0.5\% incidence of Phytophthora blight and dieback, whereas 'Lee's Dark Purple' had 3.8\% disease incidence across all nurseries surveyed.
\end{abstract}

Phytophthora ramorum Werres, De Cock \& Man in't Veld, the causal agent of sudden oak death on coast live oak (Quercus agrifolia), tanoak (Lithocarpus densiflorus), and California black oak (Q. kellogii), is established in areas of 14 coastal counties of northern California and 1 county in southern Oregon and could pose a serious threat to the health of red (black) and white oak species in the eastern forests of the United States if this pathogen were to be introduced and become established $(33,34,42,43)$. In 2003, Q. ilex (a member of the white oak group) was found naturally infected with $P$. ramorum in the United Kingdom (11). To date, no species of white oak have been found with the disease in the United States; however, greenhouse studies have demonstrated that

Corresponding author: C. Warfield

E-mail: cywarfield@ucdavis.edu

Current address of C. Warfield: University of California Cooperative Extension, Half Moon Bay, CA 94019.

Current address of J. Hwang: Department of Entomology, Soils, and Plant Sciences, Clemson University, Clemson, SC 29634.

Accepted for publication 18 October 2007.

doi:10.1094/PDIS-92-3-0474

(C) 2008 The American Phytopathological Society
$P$. ramorum can cause stem lesions on two white oak species ( $Q$. alba and $Q$. prinus) in addition to nine other Eastern forest species evaluated using artificial inoculation (42). P. ramorum primarily attacks the vascular system of susceptible live oak and tanoak trees just beneath the bark, girdling and killing the tree $(10,34)$. The most common symptoms on other hosts are leaf lesions, shoot blight, and stem dieback; however, infections usually are not fatal $(10,29,30,41)$.

$P$. ramorum has a broad host range which currently includes 20 plant families and 35 genera (49). As of February 2007, there were 45 proven hosts of $P$. ramorum, including 9 species currently grown as nursery crops in North Carolina. Among these nine plant species are six genera recognized as highly susceptible to $P$. ramorum in U.S. nursery settings $(30,38,48)$. These include Camellia, Rhododendron (excluding azaleas), and Viburnum, which had the highest disease incidence of $P$. ramorum in nursery surveys conducted in California, Oregon, and Washington in 2003, 2004, and 2005 (44). These three genera, in addition to Pieris, Kalmia, and Syringa, also have been found infected with $P$. ramorum in container nurseries in Europe $(1,2,16,25,51,53)$.

The first detection of $P$. ramorum in a U.S. nursery occurred in January 2001 on a containerized rhododendron in Califor- nia, followed by nursery detections in Oregon and Washington in May and June 2003 (6). During 2003 and early 2004, P. ramorum-infected camellia plants were inadvertently shipped from a California nursery supplier to wholesale growers and dealers in 40 states. Trace-forward inspections resulted in the detection and destruction of infected plants at 122 nursery or dealer sites in over 20 states in 2004, including nine sites in North Carolina (45). In 2005, 99 sites in seven states had nursery-related $P$. ramorum detections $(5,47)$. In 2006, $P$. ramorum was detected in 62 nurseries in 11 states $(7,50)$. $P$. ramorum can move on infected nursery stock from the west to east coast of the United States and those infected plants, if placed in the landscape, could expose eastern oak woodlands to a serious exotic pathogen. To date, however, there have been no confirmed cases where $P$. ramorum has become established in the eastern landscape or woodlands from an infected nursery plant. To address spread of $P$. ramorum in the nursery industry, hosts and associated hosts in California, Oregon, and Washington are regulated as nursery stock and require annual inspection and testing before they can be shipped interstate (46).

Symptoms of leaf blight and dieback caused by other Phytophthora spp. have been widely reported on nursery-grown ornamental crops. During nursery surveys in the early $1970 \mathrm{~s}$, P. cactorum was isolated from branches and crowns of rhododendron surveyed in the Pacific Northwest, northern California, the southeastern United States, and the New England states (18). P. cambivora was isolated in the early 1970s from shoots of a hybrid rhododendron grown in a Denmark nursery (23). Nursery surveys conducted during the summer months in North Carolina in the late 1970s found P. cactorum, P. citricola, $P$. heveae, and $P$. nicotianae causing blight and dieback symptoms in hybrid rhododendron (3). More recently in Oregon, the species listed above plus $P$. cinnamomi, $P$. citrophthora, $P$. gonapodyides, $P$. hibernalis, $P$. syringae, and $P$. ramorum were isolated from rhododendron leaves exhibiting blight and dieback symptoms during statewide nursery surveys in 2001 to 2003 (28). Because symptoms caused by $P$. ramorum cannot be distinguished from 
other common Phytophthora spp. by visual inspection, diagnosis of $P$. ramorum in infected plant tissue is determined by morphological characteristics of the isolate (52) and DNA analysis by polymerase chain reaction (PCR; 26).

The objective of this study was to survey ornamental nurseries in North Carolina to document whether or not $P$. ramorum was present, as well as to determine the status of Phytophthora blight and dieback incidence in nursery crops in North Carolina. A survey of hybrid rhododendron, Pieris spp., and Viburnum spp. was conducted during spring 2003. Camellia was not recognized as a host of $P$. ramorum at the time and was not included in the survey.

\section{MATERIALS AND METHODS}

Selection of nurseries. A letter was mailed to all North Carolina state-certified nurseries growing broadleaf evergreens. The letter requested nursery participation in the Pilot National Survey if (i) hybrid rhododendron, Pieris spp., Kalmia latifolia, or Viburnum spp. were being grown at the nursery and (ii) if liners or cuttings had been bought in from west coast or European nurseries. Fourteen nurseries in the piedmont and mountain regions of North Carolina (Fig. 1), ranging in size from 0.24 to 24 ha, were selected for the survey based on the criteria listed above and their willingness to participate. One nursery produced field-grown stock while the others all produced containerized plants. Among the nurseries, seven grew only hybrid rhododendron, five grew both hybrid rhododendron and Pieris spp., one grew Pieris spp. and Viburnum spp., and one grew all three hosts.

Nursery survey and plant sampling. The first nursery was surveyed on 7 May and the last nursery on 12 June 2003. New growth of target plants had emerged but was not fully mature. At some western North Carolina locations with high altitude, nursery operators had just finished respacing plants after overwintering them in tight blocks. The entire population of plants of the three host species of interest was surveyed at each nursery. A map of the nursery layout was provided by the owner or plotted freehand to establish block numbers for future reference. The survey team, including the authors and their technicians, previously had held a training session so that all surveyors were familiar with symptom recognition. Surveyors visually examined each plant in a block, noted the species and cultivar, and recorded the total number of plants in the block on a data sheet. Any plant with symptoms suspect for Phytophthora leaf blight or dieback was counted and recorded as infected. A maximum of 40 symptomatic plants were sampled at a given nursery. Symptomatic foliage or shoot tips from individual plants were collected and placed in a resealable plastic bag marked with the sample number, cultivar, block number, and a nursery code along with the date. A wooden garden stake was placed in the pot of the sampled plant and the sample number was recorded on the data sheet and stake for future reference. Hand pruners were sprayed with $70 \%$ alcohol between samples. Bagged samples were placed in an insulated ice chest for transport to the laboratory, where they subsequently were stored at $4^{\circ} \mathrm{C}$ prior to processing.

Detection of Phytophthora spp. in samples. Generally, 6-mm-diameter leaf disks were cut from the margin of symptomatic tissue using a cork borer. Petiole and stem tissue samples were dissected into 2- to 3-mm-long pieces. Up to five leaf disks or tissue pieces from a single plant sample were plated onto PARP medium with cornmeal agar (22). Culture plates were incubated at $20^{\circ} \mathrm{C}$ and examined weekly beginning at 4 days for up to 6 weeks. Hyphal tips of resulting colonies were subcultured on cornmeal agar, and morphological characters were used to group isolates and identify to species when possible $(13,39)$.

The identity of each group of isolates was confirmed by a restriction fragment length polymorphism PCR identification method that utilizes a set of universal primers, internal transcribed spacer (ITS) 5 and ITS4, to amplify the ITS region of rDNA, followed by a comparison of restriction enzyme digest products of the ITS region (32). Several isolates, representing each group of Phytophthora isolates recovered during our survey, were grown in pea broth for 7 days at room temperature and DNA was extracted by a hexadecyltrimethylammonium bromide procedure as previously described (20). The restriction enzymes HaeIII, MspI, or RsaI were used to digest the amplified DNA fragments, confirming the identity of two groups of our isolates. A second PCR-based identification method (9) was necessary for confirmation of the third group of Phy-

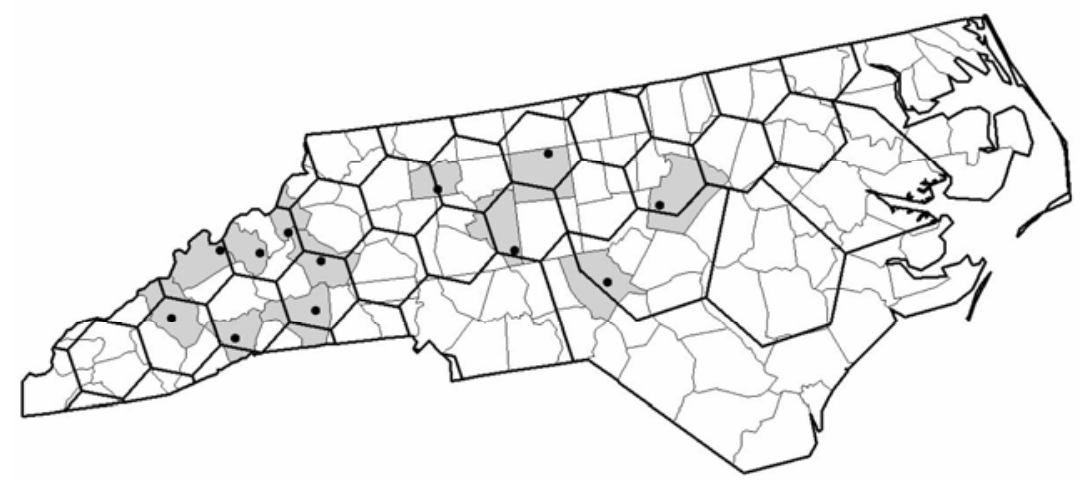

Fig. 1. Sudden oak death risk/hazard map for North Carolina. The even-sided hexagons are considered high-risk areas for establishment of Phytophthora ramorum based on the presence of likely hosts, potential pathways of introduction (nurseries), and climatic factors within the region. Counties shown in gray represent the location, and the dots represent the zip code of the nurseries included in the 2003 Pilot National Survey in North Carolina. Map courtesy of William Smith, United States Department of Agriculture Forest Service, Research Triangle Park, NC. tophthora isolates, which could not be identified using the method of Ristaino et al. (32). The second protocol utilized primers ITS6 and ITS4 and the restriction enzymes $A l u \mathrm{I}$ and $M s p \mathrm{I}$ with a final concentration of $\mathrm{MgCl}_{2}$ in the master mix adjusted to $2 \mathrm{mM}$ (8). Amplified PCR product was digested at $37^{\circ} \mathrm{C}$ for $3 \mathrm{~h}$ followed by $65^{\circ} \mathrm{C}$ for $10 \mathrm{~min}$. The digested product was resolved and visualized on a $1.5 \%$ agarose gel containing ethidium bromide $(0.5 \mu \mathrm{g} / \mathrm{ml})$ at $55 \mathrm{~mA}$ for $2 \mathrm{~h}$. Fragment sizes in base pairs were calculated with the shareware software program SEQAID II, which is available online from Kansas State University (31).

At the time tissue samples were prepared for culture isolation, an additional leaf disk or stem piece from the same plant sample was bulked with tissue from up to four other plant samples from two or more blocks within a nursery. The bulked tissue was frozen in liquid nitrogen and macerated in a Mini-BeadBeater-1 (Biospec Products Inc., Bartlesville, OK). Ground tissue was processed for DNA extraction by use of a DNeasy Plant Mini Kit (Qiagen, Inc., Valencia, CA) following the manufacturer's protocol. Total genomic DNA was eluted in a final volume of 100 $\mu \mathrm{l}$ and stored at $-20^{\circ} \mathrm{C}$. The extracted DNA was amplified and visualized for the presence of $P$. ramorum using a nested-PCR assay approved for the Pilot National Survey by the United States Department of Agriculture Animal and Plant Health Inspection Service (USDA-APHIS; 26). DNA of $P$. ramorum, provided by L. Levy (USDA-APHIS, Beltsville, MD), was used as a positive control that resulted in a 291bp amplification product after the second round of PCR.

\section{RESULTS}

Nursery survey. Overall, 229,132 hybrid rhododendron, 1,727 Pieris spp., and 2,896 Viburnum spp. were surveyed across the 14 North Carolina nurseries, with a total of 347 plant samples col- 
lected (Table 1). The survey crew typically consisted of five trained surveyors. The time required to survey and collect samples was highly variable. For instance, Nursery B was a 1.5-h drive each way and required over $6 \mathrm{~h}$ onsite for the five-person team to survey. Nursery F was a 3-h drive but, with only 2,400 rhododendrons and 170 Pieris spp. plants, took only about $1 \mathrm{~h}$ for the team to survey. In all, we spent about 317 man-hours to survey the 14 nurseries.

Phytophthora spp. isolated. $P$. ramorum was not isolated from any of the 347 plant samples collected, nor was it detected by the nested-PCR protocol (Table 1). In all, 92 nested PCR assays consisting of up to five plant samples per reaction were run. We found 9 of 92 reactions suspect for $P$. ramorum after running the nested-PCR assay. However, the products were slightly larger in size and the intensity of the products was faint compared with the positive control (Fig. 2a). When the product of the first-round PCR $(P$. ramorum specific primer set) from each suspect, composite sample was resolved and visualized on a gel, no amplicon of the appropriate size $(687 \mathrm{bp})$ for $P$. ramorum was observed (Fig. 2b). P. ramorum was not recovered from any tissue samples cultured in which the tentatively false positives were observed.

Although $P$ ramorum was not detected, three other Phytophthora spp. were isolated from $29.4 \%$ of the plant samples collected at 10 of the 14 nurseries surveyed
(Table 1). Four nurseries had no detectable Phytophthora spp. P. citricola, P. cambivora, and $P$. cactorum were recovered from both hybrid rhododendron and Pieris spp. No isolates of Phytophthora were recovered from Viburnum spp. P. citricola was detected in seven nurseries, $P$. cambivora in five nurseries, and $P$. cactorum in two nurseries. Among the Phytophthora isolates recovered, $P$. citricola $(51 \%)$ and $P$. cambivora $(48 \%)$ were isolated with similar frequency on the hybrid rhododendron samples collected, but $P$. citricola $(91.3 \%)$ was isolated more frequently than P. cambivora (4.3\%) on Pieris spp. P. cactorum only accounted for 1.0 and $4.3 \%$ of the Phytophthora isolates recovered from rhododendron and Pieris spp., respectively. $P$. citricola was the only species of Phytophthora isolated at 4 of the 10 nurseries, and $P$. cambivora was the only species recovered at 2 of the 10 nurseries (Table 1). Both P. citricola and P. cambivora were recovered from three nurseries. $P$. cambivora and $P$. cactorum, and P. citricola and $P$. cactorum, both were detected in one nursery each. In both nursery A and nursery F, two Phytophthora spp. were recovered from the same cultivar within the same nursery block but on separate plants (Table 2). In the other three nurseries where multiple Phytophthora spp. were detected, only one species was recovered within a nursery block (Table 2).

Disease incidence by host surveyed. In hybrid rhododendron across all nurseries surveyed, incidence of foliar blight and dieback symptoms averaged $2.4 \%$, with a range of 0.5 to $8.6 \%$ depending on the nursery (Table 1). However, based on the actual recovery of Phytophthora spp. from these nurseries, the average disease incidence averaged $0.6 \%$, with a range of 0 to $5.9 \%$ for all 229,132 hybrid rhododendrons surveyed. Typical symptoms of foliar blight and dieback on rhododendron included diffuse, brownish lesions on the tips or margins of expanding immature leaves or v-shaped lesions starting at the petiole attachment. Eventually, the discoloration extended down the petiole and into the stem. Subsequently, the pathogen moved from the initially infected leaf petiole to adjoining petioles in the whorl, moving upward into new leaves and causing a dieback symptom. However, at the time of the survey, the pathogen had not progressed down the stems from infected new growth into mature tissue from the previous growing season.

At seven nurseries, incidence of foliar blight and dieback in Pieris spp. ranged from 0 to $49.6 \%$, with a mean of $10 \%$ (Table 1). Based on the actual recovery of Phytophthora spp. from these nurseries, the average disease incidence was $8.7 \%$ for all 1,727 Pieris spp. surveyed. Symptoms in Pieris spp. started at the leaf tip or margin and spread irregularly down the midrib into the leaf petiole and stem. Discolored tissues were brown in color. The blighted tips often had a shepherd's crook appearance. The flower racemes also were brown and necrotic.

Table 1. Incidence of blight and dieback, and results of polymerase chain reaction (PCR) and culture isolation for detection of Phytophthora ramorum and other Phytophthora spp. in 347 plant samples collected at 14 North Carolina nurseries in 2003

\begin{tabular}{|c|c|c|c|c|c|c|c|c|}
\hline \multirow[b]{2}{*}{ Nursery code } & \multirow[b]{2}{*}{ County } & \multirow[b]{2}{*}{ No. of plants ${ }^{c}$} & \multirow[b]{2}{*}{ Dieback $(\%)^{\mathrm{d}}$} & \multirow[b]{2}{*}{ Samples $^{\mathrm{e}}$} & \multicolumn{2}{|c|}{ P. ramorum } & \multicolumn{2}{|c|}{ Phytophthora spp. } \\
\hline & & & & & PCR + & Cult + & Cult - & Cult + \\
\hline \multicolumn{9}{|c|}{ Hybrid rhododendron } \\
\hline $\mathrm{A}$ & Chatham & 5,052 & 3.2 & 41 & 0 & 0 & 38 & 2 Pcit; 1 Pcam \\
\hline $\mathrm{B}$ & Guilford & 92,732 & 0.1 & 22 & 0 & 0 & 20 & 2 Pcit \\
\hline $\mathrm{E}$ & Yadkin & 2,455 & 8.6 & 12 & 0 & 0 & 12 & 0 \\
\hline $\mathrm{F}$ & Burke & 2,402 & 6.8 & 42 & 0 & 0 & 10 & 6 Pcit; 26 Pcam \\
\hline $\mathrm{G}$ & Avery & 2,305 & 0.6 & 10 & 0 & 0 & 10 & 0 \\
\hline $\mathrm{H}$ & Yancey & 14,361 & 0.1 & 14 & 0 & 0 & 10 & 4 Pcam \\
\hline $\mathrm{I}$ & Madison & 59,432 & 0.2 & 41 & 0 & 0 & 31 & 10 Pcit \\
\hline $\mathrm{J}$ & Haywood & 34,927 & 0.2 & 29 & 0 & 0 & 8 & 1 Pcat; 20 Pcit \\
\hline $\mathrm{K}$ & Henderson & 960 & 2.1 & 10 & 0 & 0 & 10 & 0 \\
\hline M & Moore & 324 & 2.1 & 7 & 0 & 0 & 2 & 5 Pcam \\
\hline $\mathrm{N}$ & Moore & 13,945 & 2.1 & 41 & 0 & 0 & 39 & 2 Pcam \\
\hline $\mathrm{P}$ & Guilford & 187 & 0.5 & 1 & 0 & 0 & 1 & 0 \\
\hline $\mathrm{T}$ & Randolph & 50 & 4.0 & 2 & 0 & 0 & 2 & 0 \\
\hline Total & & 229,132 & $\bar{X}=2.4$ & 272 & 0 & 0 & 194 & 79 \\
\hline \multicolumn{9}{|l|}{ Pieris spp. } \\
\hline $\mathrm{F}$ & Burke & 169 & 3.6 & 1 & 0 & 0 & 0 & 1 Pcit \\
\hline $\mathrm{J}$ & Haywood & 113 & 49.6 & 2 & 0 & 0 & 0 & 2 Pcit \\
\hline $\mathrm{K}$ & Henderson & 234 & 1.7 & 2 & 0 & 0 & 0 & 2 Pcit \\
\hline $\mathrm{L}$ & Rutherford & 340 & 0.0 & 0 & $\ldots$ & $\ldots$ & $\ldots$ & $\ldots$ \\
\hline $\mathrm{M}$ & Moore & 386 & 1.6 & 4 & 0 & 0 & 2 & 1 Pcat; 1 Pcam \\
\hline $\mathrm{P}$ & Guilford & 454 & 14.1 & 30 & 0 & 0 & 14 & 16 Pcit \\
\hline $\mathrm{T}$ & Randolph & 31 & 0.0 & 0 & $\ldots$ & $\ldots$ & $\ldots$ & $\ldots$ \\
\hline Total & $\ldots$ & 1,727 & $\bar{X}=10.0$ & 39 & 0 & 0 & 16 & 23 \\
\hline
\end{tabular}

a Results for PCR and culture (Cult) are positive (+) or negative (-).

${ }^{\mathrm{b}}$ Phytophthora spp. were identified as P. citricola (Pcit), P. cambivora (Pcam), or P. cactorum (Pcat).

${ }^{c}$ Number of plants surveyed.

${ }^{\mathrm{d}}$ Dieback percentage is the total number of plants with leaf lesions, foliar blight, or dieback symptoms compared to the total number of plants surveyed at a nursery.

e Number of samples collected. 
Phytophthora spp. were not isolated from any of the Viburnum samples collected (data not shown).

Disease incidence among cultivars of hybrid rhododendron. About 90 cultivars were in cultivation among the 13 nurseries surveyed that were growing rhododendron. Forty of these cultivars were represented by at least 500 plants per cultivar. The cultivars with the greatest number of plants being grown across all nurseries included: 'English Roseum' (35,561 plants), 'Roseum Elegans' (33,143 plants), 'Nova Zembla' (21,397 plants), 'PJM' (13,104 plants), and 'Chionoides' (9,456 plants), followed by 'Catawbiense Album,' 'Catawbiense Boursault,' and 'Roseum Pink,' with more than 8,500 plants surveyed for each of these cultivars. Based on recovery of Phytophthora spp., Phytophthora blight and dieback was confirmed for 12 hybrid rhododendron cultivars, in addition to a number of unlabeled cultivars at the time of the survey (Table 3). Incidence of Phy- tophthora blight and dieback among these 12 cultivars was $0.6 \%$ or less, with one exception. Disease incidence was higher $(3.8 \%)$ in 'Lee's Dark Purple' but the number of plants surveyed was small, with only 1,277 plants surveyed across four nurseries (Table 3).

Disease incidence among Pieris spp. A relatively small number of Pieris spp. plants $(n=1,700)$ were surveyed. Among four nurseries where 649 Pieris japonica 'Mountain Fire' were grown, disease incidence was $6.5 \%$ (Table 4). An unlabeled group of Pieris plants at nursery $\mathbf{J}$ had almost 50\% disease incidence among 133 plants (Table 1).

\section{DISCUSSION}

Phytophthora ramorum was neither isolated nor detected by PCR on any of the nursery crops surveyed in North Carolina during May and June 2003. Nine amplified products after the nested-PCR protocol yielded bands that could be suspect for the presence of $P$. ramorum. However, those bands were slightly larger than the amplified product of $P$. ramorum and further visualization of the first-round products from each reaction, as well as the failure to isolate this pathogen in culture, led us to conclude that these reactions were false positives. The primer sets used in this study for the detection of $P$. ramorum can cross-react with a limited number of other Phytophthora spp. including P. cambivora $(4,10,15,27)$. Due to the high sensitivity of the nested-PCR protocol, cross-contamination from other samples or the laboratory environment can also easily cause false-positive reactions. $P$. cambivora was isolated from tissue samples composing two of the false-positive composite samples, but no Phytophthora spp. were recovered from tissue samples from the other seven false-positive composite samples.

Favorable climatic conditions for growth of $P$. ramorum, based on laboratory studies, include ambient temperatures between
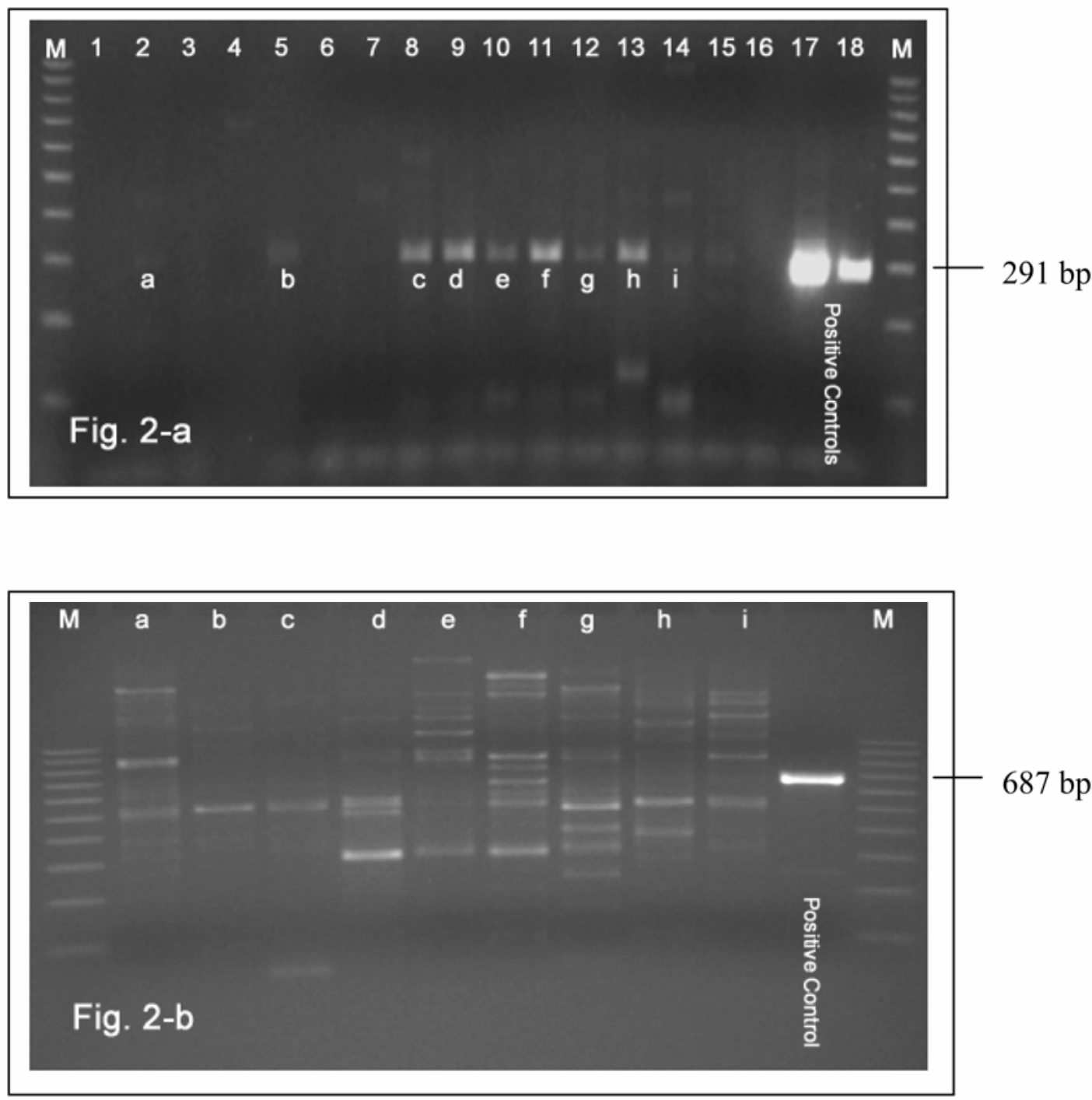

Fig. 2. a, Nine false-positive reactions (labeled a to i) for Phytophthora ramorum were obtained after a nested-polymerase chain reaction (PCR) assay performed on plant samples collected in North Carolina nurseries in 2003. b, Visualization of only first-round PCR products supports nonspecific amplification in the nested-PCR assay, as indicated by the absence of a 687-bp amplicon for samples a to i compared with the P. ramorum DNA positive control. Molecular weight markers $(\mathrm{M})$. 
2 and $28^{\circ} \mathrm{C}(12)$, with an optimum of $20^{\circ} \mathrm{C}$ (52), and at least $12 \mathrm{~h}$ of leaf wetness over 10 days or more for the best expression of was not available for individual nurseries in our survey, data collected by the State Climate Office of North Carolina was obtained from weather stations located in closest proximity to each nursery site. For the 2 weeks preceding each sampling date, symptoms (48). Although weather data

the average daily temperatures ranged from 13.6 to $24.6^{\circ} \mathrm{C}$ across all nurseries. The duration of leaf wetness could not be determined; however, the number of days with measurable precipitation ranged from 5 to 13 days in the 14 days prior to sampling at each of the nurseries surveyed. Although ambient temperatures were within the favorable range for $P$. ramorum, the frequency and diversity of other Phy-

Table 2. Incidence of blight and dieback, and Phytophthora spp. isolated in 2003 from hybrid rhododendron and Pieris spp. within nursery blocks at 10 nurseries surveyed in North Carolina

\begin{tabular}{|c|c|c|c|}
\hline $\begin{array}{l}\text { Nursery, } \\
\text { block }^{\mathrm{a}}\end{array}$ & Host & Phytophthora spp. & $\begin{array}{c}\text { Dieback } \\
(\%)^{\mathbf{b}}\end{array}$ \\
\hline \multicolumn{4}{|l|}{ A } \\
\hline 15 & Rhododendron 'English Roseum' & P. cambivora, P. citricola & 5.0 \\
\hline 19 & Rhododendron 'English Roseum' & P. citricola & 4.1 \\
\hline \multicolumn{4}{|c|}{ The } \\
\hline 142 & Rhododendron 'Catawbiense Album' & P. citricola & 0.6 \\
\hline 169 & Rhododendron 'Roseum Elegans' & P. citricola & 0.8 \\
\hline \multicolumn{4}{|c|}{ 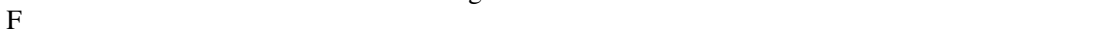 } \\
\hline 1 & Rhododendron 'Lee's Dark Purple' & P. cambivora & 22.2 \\
\hline 1 & Rhododendron 'Nova Zembla' & P. cambivora & 25.7 \\
\hline 1 & Rhododendron Roseum Elegans & P. cambivora, $P$. citricola & 22.9 \\
\hline 2 & Pieris japonica 'Mountain Fire' & P. citricola & 3.6 \\
\hline 3 & Rhododendron 'English Roseum' & P. cambivora, $P$. citricola & 9.5 \\
\hline 4 & Rhododendron 'Catawbiense Boursault' & P. cambivora & 20.0 \\
\hline 4 & Rhododendron 'English Roseum' & P. cambivora, P. citricola & 11.3 \\
\hline 5 & Rhododendron 'English Roseum' & P. cambivora & 0.6 \\
\hline \multicolumn{4}{|c|}{ (1) } \\
\hline 1 & Rhododendron cvs. & P. cambivora & 0.2 \\
\hline 17 & Rhododendron 'Catawbiense Boursault' & P. cambivora & 1.7 \\
\hline 18 & Rhododendron cvs. & P. cambivora & 0.8 \\
\hline 21 & Rhododendron 'Catawbiense Grandiflorum' & P. cambivora & 0.6 \\
\hline \multicolumn{4}{|c|}{ 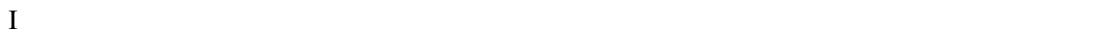 } \\
\hline 6 & Rhododendron 'English Roseum' & P. cambivora & 0.3 \\
\hline 15 & Rhododendron 'Chionoides' & P. citricola & 0.1 \\
\hline 33 & Rhododendron 'Scintillation' & P. citricola & 5.4 \\
\hline 36 & Rhododendron 'Roseum Elegans' & P. citricola & 1.6 \\
\hline 42 & Rhododendron Roseum Elegans' & P. citricola & 2.1 \\
\hline 50 & Rhododendron 'English Roseum' & P. citricola & 2.9 \\
\hline 53 & Rhododendron 'English Roseum' & P. citricola & 0.3 \\
\hline \multicolumn{4}{|c|}{ 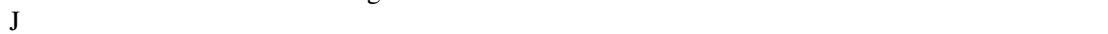 } \\
\hline 1 & Rhododendron 'Blue Peter' & P. citricola & 1.1 \\
\hline 1 & Pieris sp. & P. citricola & 50.0 \\
\hline 2 & Pieris sp. & P. citricola & 40.0 \\
\hline 3 & Rhododendron cvs. & P. citricola & 0.1 \\
\hline 4 & Rhododendron cvs. & P. citricola & 0.3 \\
\hline 5 & Rhododendron 'Roseum Elegans' & P. citricola & 0.4 \\
\hline 6 & Rhododendron 'Roseum Elegans' & P. cactorum & 1.3 \\
\hline 9 & Rhododendron 'Catawbiense Boursault' & P. citricola & 0.8 \\
\hline 10 & Rhododendron cvs. & P. citricola & 1.4 \\
\hline 16 & Rhododendron cvs. & P. citricola & 0.6 \\
\hline \multicolumn{4}{|c|}{ (1) } \\
\hline 2 & Pieris sp. & P. citricola & 6.8 \\
\hline 5 & Pieris sp. & P. citricola & 12.5 \\
\hline \multicolumn{4}{|l|}{ M } \\
\hline 2 & Rhododendron cvs. & P. cambivora & 3.8 \\
\hline 3 & P. japonica cvs. & P. cactorum & 0.6 \\
\hline 4 & P. japonica cvs. & P. cambivora & 3.9 \\
\hline 7 & Rhododendron cvs. & P. cambivora & 1.9 \\
\hline \multicolumn{4}{|c|}{ 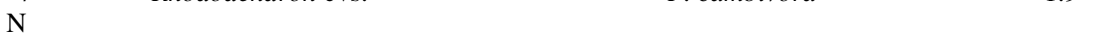 } \\
\hline 55 & Rhododendron 'Yaku Princess' & P. cambivora & 2.0 \\
\hline 81 & Rhododendron 'English Roseum' & P. cambivora & 2.9 \\
\hline \multicolumn{4}{|c|}{ Noverecrar } \\
\hline A5 & P. japonica 'Scarlet O'Hara' & P. citricola & 25.0 \\
\hline A5 & P. japonica 'Scarlet O'Hara' & P. citricola & 20.0 \\
\hline A5 & P. japonica 'Scarlet O'Hara' & P. citricola & 6.0 \\
\hline A5 & P. japonica 'Mountain Fire' & P. citricola & 26.7 \\
\hline A5 & P. japonica 'Mountain Fire' & P. citricola & 18.0 \\
\hline
\end{tabular}

${ }^{a}$ Only nurseries in which Phytophthora spp. were recovered are included in table. Blocks represented by different numbers within a nursery were physically separate from each other.

${ }^{b}$ Dieback represents the percentage of plants within a block exhibiting foliar blight or dieback symptoms for a given cultivar or species. tophthora spp. recovered may have been higher had the survey been conducted later in the season, when conditions would be more favorable for warm-season Phytophthora spp. such as $P$. nicotianae. We did find a low incidence of Phytophthora blight and dieback caused by other Phytophthora spp. in hybrid rhododendron $(0.6 \%)$ and Pieris spp. (8.7\%). Most hybrid rhododendron cultivars surveyed had less than $0.5 \%$ incidence of Phytophthora dieback across all nurseries.

$P$. citricola and $P$. cambivora were the most frequently isolated Phytophthora spp. on rhododendron in this survey. Although $P$. citricola has been encountered commonly in the past, the occurrence of $P$. cambivora as a blight and dieback pathogen of rhododendron had not been reported previously in North Carolina (21). P. cambivora was as prevalent as $P$. citricola, with recovery at five nurseries growing rhododendron and Pieris spp. in our survey. $P$. cactorum also was isolated from one rhododendron plant in our survey. In nursery surveys in Minnesota from 2002 to 2005, P. citricola (55\%), P. cactorum (16\%), and P. citrophthora (17\%) were the most common Phytophthora spp. isolated from rhododendron (36). P. cambivora and $P$. cactorum previously have been reported causing foliar blight on rhododendron in Oregon (28). P. cactorum, P. citricola, $P$. citrophthora, and $P$. nicotianae were isolated from nursery-grown rhododendron in Ohio, where they were reported to be causing necrotic foliar lesions or twig dieback symptoms during the month of August (40).

In addition to $P$. ramorum, several Phytophthora spp. causing leaf blight and dieback of rhododendron have been reported recently. $P$. hibernalis was found causing leaf spots on nursery-grown rhododendron in California and Oregon (4). $P$. inflata was isolated from leaf lesions or blighted twigs in nursery-grown Rhododendron ponticum in Scotland (35) and rhododendron in Ohio (40). P. insolita was isolated from nursery-grown rhododendron in Ohio, where it was causing foliar lesions (40). P. hedraiandra was detected in a nursery in Minnesota, where this pathogen was causing leaf lesions and shoot dieback on Rhododendron cv. Mikkeli (37). Shoot blight caused by $P$. tropicalis was reported on $R$. catawbiense cv. Maximum Roseum at a garden center in Virginia (19).

$P$. citricola was the most frequent Phytophthora sp. isolated from the Pieris plants sampled in our survey. $P$. cactorum also was recovered from Pieris spp. in this survey, but from only one plant. P. citricola recently was found causing a foliar blight in containerized nursery stock of Pieris japonica 'Flamingo' grown in California (24). Phytophthora citricola and $P$. citrophthora caused serious losses on Pieris japonica in the early 1970s in Ohio nurseries $(14,17)$. In a 2003 nursery survey 
in Oregon, Phytophthora cambivora, $P$. cinnamomi, $P$. nicotianae, $P$. syringae, $P$. citrophthora, and $P$. heveae were reported from Pieris spp. (28). Leaf spots and necrosis of shoot tips caused by $P$. tropicalis was reported on Pieris japonica cv. Temple Bells at a garden center in Virginia (19).

Across the 10 nurseries in this survey where Phytophthora spp. were isolated, incidence of Phytophthora blight and dieback was $0.6 \%$ for hybrid rhododendron. In a similar North Carolina survey in 1980, Benson et al. (3) found an incidence of $2.8 \%$ in hybrid rhododendron at 10 nurseries surveyed. Among cultivars in which Phytophthora spp. were recovered, disease incidence was surprisingly low, with less than $0.5 \%$ incidence for most cultivars across all nurseries surveyed in 2003. In contrast, disease incidence for a given cultivar was generally higher for that cultivar when evaluated within a single nursery or nursery block compared with the overall disease incidence across all nurseries growing the cultivar. Three nurseries had a least one block of either rhododendron or Pieris cultivars with 20 to $50 \%$ disease incidence. Over $22 \%$ of each of three rhododendron cultivars growing in one nursery block were infected with Phytophthora spp. at nursery F.

Phytophthora citricola and P. cactorum, $P$. citricola and $P$. cambivora, and $P$. cambivora and $P$. cactorum were isolated from rhododendron or Pieris spp. in the same or separate nursery blocks within a given nursery. The current sampling protocol for the USDA-APHIS National Nursery Survey recommends sampling a representative number of plants within a nursery block, but not every single plant must be sampled (48). The presence of multiple Phytophthora spp. within the same nursery or nursery block demonstrates the potential that exists for failure to detect $P$. ramorum in nursery surveys even though a representative sample is being taken.

The overall low incidence of disease observed in our survey may be due to more effective disease management strategies as well as the fact that our survey was conducted early in the growing season, before optimal conditions for disease development for most warm-season Phytophthora spp. Limited fungicide data was provided at 7 of the 14 nurseries surveyed. From the information obtained, a monthly, mistblown fungicide application of fosetyl-Al beginning in mid-April and continuing until October was common. Fungicide applications were made in at least three nurseries within 2 to 3 weeks prior to our survey, which may have masked disease symptoms or potentially influenced our success in isolating Phytophthora spp. from the tissue sampled. Fungicides containing the active ingredient mancozeb were used by five of the six nurseries. The use of thiophanate-methyl, mefenoxam, propiconazole, iprodione, and myclobutanil also was reported. Fungicides had not yet been applied at the nursery in our survey with the highest Phytophthora blight incidence on rhododendron.

Incidence of Phytophthora blight and dieback was greater in Pieris spp. than in hybrid rhododendron, even though the individual cultivars or species of Pieris spp. were considerably fewer than the hybrid rhododendron. Although the numbers of Pieris spp. and Viburnum spp. surveyed were small, these two host genera have been associated with outbreaks of $P$. ramorum in nurseries in the United States and Europe $(16,24,25,28,52,53)$. We recovered $P$. citricola, $P$. cambivora, and $P$. cactorum from diseased Pieris spp. in this survey, but no Phytophthora spp. from Viburnum spp.

Regular nursery surveys are important to monitor the presence of Phytophthora spp. causing blight and dieback in ornamental crops for early detection of the regulated pathogen $P$. ramorum given the continuous movement of nursery stock in the United States. Our survey established that, as of 2003, P. ramorum had not been introduced into representative nurseries in North Carolina. The number of nurseries surveyed represented less than $5 \%$ of statecertified nurseries in North Carolina growing broadleaf evergreens, leaving the possibility that $P$. ramorum could have been introduced in North Carolina nurseries but went undetected. In addition, because camellias were not a recognized host at the time of the survey, no camellia plants were surveyed. Today, 29 hosts or associated hosts of $P$. ramorum are being grown throughout the North Carolina nursery industry. Trace-forward surveys in spring 2004 of containerized Camellia spp. shipped from a large southern California nursery supplier did detect the presence of $P$. ramorum at nine wholesale nurseries or dealer sites in North Carolina (45). Perimeter surveys of those locations in 2004, 2005, and 2006 failed to find any evidence that $P$. ramorum had been introduced to the

Table 3. Incidence of Phytophthora blight and dieback among cultivars of hybrid rhododendron among North Carolina nurseries surveyed in 2003

\begin{tabular}{lcccccc}
\hline & \multicolumn{2}{c}{ No. of nurseries $^{\mathbf{a}}$} & & \multicolumn{2}{c}{ No. of plants } & \\
\cline { 2 - 3 } Cultivar $^{\mathbf{b}}$ & Growing & Infected $^{n}$ & & Surveyed & Infected $^{\mathbf{c}}$ & Dieback (\%) $^{\mathbf{d}}$ \\
\hline Blue Peter & 2 & 1 & & 160 & 1 & 0.6 \\
Catawbiense Album & 6 & 1 & & 9,062 & 29 & 0.3 \\
Catawbiense Boursault & 7 & 3 & & 8,843 & 24 & 0.3 \\
Catawbiense Grandiflorum & 5 & 2 & & 6,543 & 15 & 0.2 \\
Chionoides & 7 & 1 & & 9,456 & 40 & 0.4 \\
English Roseum & 12 & 5 & & 35,561 & 163 & 0.5 \\
Lee's Dark Purple & 4 & 1 & & 1,277 & 48 & 3.8 \\
Nova Zembla & 8 & 2 & & 21,397 & 62 & 0.3 \\
Roseum Elegans & 9 & 5 & & 33,143 & 105 & 0.3 \\
Roseum Pink & 4 & 1 & & 8,734 & 4 & 0.1 \\
Scintillation & 3 & 1 & & 6,334 & 33 & 0.5 \\
Yaku Princess & 2 & 1 & & 2,540 & 4 & 0.2 \\
Unlabeled/mixed cultivars & 6 & 3 & & 6,314 & 58 & 0.1
\end{tabular}

${ }^{a}$ Number of nurseries growing the cultivar (Growing) and number with infected plants (Infected).

b Only hybrid rhododendron cultivars in which Phytophthora spp. were recovered from collected tissue samples are included in table.

${ }^{c}$ Number of plants of a given cultivar exhibiting foliar blight or dieback symptoms across all nurseries surveyed.

${ }^{\mathrm{d}}$ Dieback represents the percentage of plants exhibiting foliar blight or dieback symptoms among a given cultivar across all nurseries surveyed.

Table 4. Incidence of Phytophthora blight and dieback among cultivars of Pieris japonica and Pieris spp. surveyed at seven North Carolina nurseries in 2003

\begin{tabular}{|c|c|c|c|c|c|}
\hline \multirow[b]{2}{*}{ Cultivar ${ }^{b}$} & \multicolumn{2}{|c|}{ No. of nurseries ${ }^{a}$} & \multicolumn{2}{|c|}{ No. of plants } & \multirow[b]{2}{*}{$\operatorname{Dieback}(\%)^{\mathrm{d}}$} \\
\hline & Growing & Infected & Surveyed & Infected $^{c}$ & \\
\hline Compacta & 1 & 0 & 90 & 0 & 0 \\
\hline Dorothy Wyckoff & 1 & 0 & 18 & 0 & 0 \\
\hline Laundry Hospital & 1 & 0 & 69 & 0 & 0 \\
\hline Mountain Fire & 4 & 2 & 649 & 42 & 6.5 \\
\hline Scarlet O'Hara & 1 & 1 & 112 & 18 & 16.1 \\
\hline White Cascade & 1 & 0 & 56 & 0 & 0 \\
\hline Unlabeled $P$. japonica cvs. & 1 & 1 & 386 & 5 & 1.3 \\
\hline Unlabeled species ${ }^{\mathrm{e}}$ & 2 & 2 & 347 & 60 & 17.3 \\
\hline
\end{tabular}

${ }^{a}$ Number of nurseries growing the cultivar (Growing) and number with infected plants (Infected).

${ }^{\mathrm{b}}$ Cultivars of $P$. japonica, unless otherwise noted.

${ }^{c}$ Number of plants of a given cultivar exhibiting foliar blight or dieback symptoms across all nurseries surveyed.

${ }^{\mathrm{d}}$ Dieback represents the percentage of plants exhibiting foliar blight or dieback symptoms among a given cultivar.

e Either P. japonica, P. floribunda, P. formosa, or other Pieris sp. 
surrounding landscape. The North Carolina Department of Agriculture and Consumer Services conducted subsequent surveys in North Carolina nurseries as part of the National Nursery Survey in 2004, 2005, and 2006. No additional detections of $P$. ramorum have been made in North Carolina since the introduction of infected camellias found during trace-forward surveys in spring $2004(5,7,45)$.

\section{ACKNOWLEDGMENTS}

The USDA-APHIS Pilot National Survey provided funding for this survey. We thank K. Parker and G. Parra for their assistance in surveying and subsequent processing of plant samples; $\mathrm{S}$. Spencer, North Carolina Department of Agriculture and Consumer Services for assistance with the mass mailing to North Carolina nurserymen; and W. Smith, USDA Forest Service, Research Triangle Park, NC, for providing the sudden oak death risk map for North Carolina.

\section{LITERATURE CITED}

1. Beales, P. A., Brokenshire, T., Barnes, A. V., Barton, V. C., and Hughes, K. J. D. 2004. First report of ramorum leaf blight and dieback (Phytophthora ramorum) on Camellia spp. in the UK. Plant Pathol. 53:524.

2. Beales, P. A., Schlenzig, A., and Inman, A. J. 2004. First report of ramorum bud and leaf blight (Phytophthora ramorum) on Syringa vulgaris in the UK. Plant Pathol. 53:525.

3. Benson, D. M., Jones, R. K., and Barker, K. R. 1982. Disease loss assessment for azalea, rhododendron, and Japanese holly in North Carolina nurseries. Plant Dis. 66:125-128.

4. Blomquist, C., Irving, T., Osterbauer, N., and Reeser, P. 2005. Phytophthora hibernalis: A new pathogen on Rhododendron and evidence of cross amplification with two PCR detection assays for Phytophthora ramorum. Online. Plant Health Progress doi:10.1094/PHP-20050728-01-HN.

5. California Oak Mortality Task Force. 2005. Sudden oak death and Phytophthora ramorum summary report: a compendium of the 2005 COMTF monthly newsletters. K. Palmieri and S. J. Frankel, eds. Published online.

6. California Oak Mortality Task Force. 2006. California Oak Mortality Task Force. Chronology. U.S.A. Phytophthora ramorum nursery chronology. Current September 2006. Published online.

7. California Oak Mortality Task Force. 2006. California Oak Mortality Task Force Report October 2006. Published online.

8. Cooke D. E. L., and Duncan J. M. 1997. Phylogenetic analysis of Phytophthora species based on the ITS1 and ITS2 sequences of ribosomal DNA. Mycol. Res. 101:667-677.

9. Cooke, D., and Smith, J. 2007. PhytIDIdentification of plant pathogenic Phytophthora species by ITS fingerprinting. Current January 2007. Published online. http://phytid.org/index.htm

10. Davidson, J. M., Werres, S., Garbelotto, M., Hansen, E. M., and Rizzo, D. M. 2003. Sudden oak death and associated diseases caused by Phytophthora ramorum. Online. Plant Health Progress doi:10.1094/PHP-2003-0707-01-DG.

11. Denman, S., Kirk, S. A., and Brasier, C. M. 2005. Phytophthora ramorum on Quercus ilex in the United Kingdom. Plant Dis. 89:1241.

12. Englander, L., Browing, M., and Tooley, P. W. 2006. Growth and sporulation of Phytophthora ramorum in vitro in response to temperature and light. Mycologia 98:365-373.

13. Erwin, D. C., and Ribeiro, O. K. 1996. Phytophthora Diseases Worldwide. The American Phytopathological Society, St. Paul, MN.

14. Gerlach, W. W .P., Hoitink, H. A. J., and Ellett,
C. W. 1974. Shoot blight and stem dieback of Pieris japonica caused by Phytophthora citricola, P. citrophthora and Botryosphaeria dothidea. Phytopathology 64:1368-1370.

15. Hayden, K. J., Rizzo, D., Tse, J., and Garbelotto, M. 2004. Detection and quantification of Phytophthora ramorum from California forests using a real-time polymerase chain reaction assay. Phytopathology 94:1075-1083.

16. Herrero, L. Toppe, B., Klemsdal, S. S., and Stensvand, A. 2006. First report of Phytophthora ramorum in ornamentals plants in Norway. Plant Dis. 90:1458

17. Hoitink, H. A. J., Daft, G., and Gerlach, W. W. P. 1975. Phytophthora shoot blight and stem dieback of azalea and pieris and its control. Plant Dis. Rep. 59:235-237.

18. Hoitink, H. A. J., and Schmitthenner, A. F. 1974. Relative prevalence and virulence of Phytophthora species involved in Rhododendron root rot. Phytopathology 64:1371-1374.

19. Hong, C. X., Richardson, P. A., and Kong, P. 2006. Phytophthora tropicalis isolated from diseased leaves of Pieris japonica and Rhododendron catawbiense and found in irrigation water and soil in Virginia. Plant Dis. 90:525.

20. Hwang, J., and Benson, D. M. 2005. Identification, mefenoxam sensitivity, and compatibility type of Phytophthora species attacking floriculture crops in North Carolina. Plant Dis. 89:185-190.

21. Hwang, J., Warfield, C. Y., Parker, K. C., and Benson, D. M. 2006. First report of Phytophthora cambivora on hybrid rhododendron in North Carolina. Online. Plant Health Progress doi: 10.1094/PHP-2006-0828-01-BR.

22. Kannwisher, M. E., and Mitchell, D. J. 1978. The influence of a fungicide on the epidemiology of black shank in tobacco. Phytopathology 68:1760-1765.

23. Koch, J. 1971. Rhododendron blight caused by Phytophthora cambivora. Friesia 9:418-425.

24. Koike, S. T., Browne, G. T., Bhat, R. G., and Lee, R. C. M. 2005. Phytophthora leaf spot and foliar blight of Pieris japonica caused by Phytophthora citricola in California. Plant Dis. 89:1013.

25. Lane, C. R., Beales, P. A., Hughes, K. J. D., Griffin, R. L., Munro, D., Brasier, C. M., and Webber, J. F. 2003. First outbreak of Phytophthora ramorum in England, on Viburnum tinus. Plant Pathol. 52:414.

26. Levy, L., and Mavrodieva, V. 2004. USDA Animal and Plant Health Inspection Service. Emergency and Domestic Programs. Phytophthora ramorum. Protocols. PCR detection and DNA isolation methods for use in the Phytophthora ramorum national program. Rev. Aug 2004. Published online.

27. Martin, F. N., Coffey, M., Berger, P., Hamelin, R., Tooley, P., Garbelotto, M., Hughes, K., and Kubisiak, T. 2006. Validation of molecular markers for Phytophthora ramorum detection and identification using a standardized library of isolates. (Abstr.) Phytopathology 96:S74 .

28. Osterbauer, N. K., Griesbach, J. A., and Hedberg, J. 2004. Surveying for and eradicating Phytophthora ramorum in agricultural commodities. Online. Plant Health Progress doi:10.1094/PHP-2004-0309-02-RS

29. Parke, J., Pscheidt, J., and Linderman, R. 2003. Phytophthora ramorum a guide for Oregon nurseries. Ore. State Univ. Ext. Serv. December 2003. EM8840.

30. Parke, J. L., Linderman, R. G., Osterbauer, N. K., and Griesbach, J. A. 2004. Detection of Phytophthora ramorum blight in Oregon nurseries and completion of Koch's postulates on Pieris, Rhododendron, Viburnum, and Camellia. Plant Dis. 88:87.

31. Rhoads, D. D., and Roufa, D. J. 1989. SEQAID II. Kansas State University, Manhattan, KS. Published online.

32. Ristaino, J. B., Madritch, M., Trout, C. L., and
Parra, G. 1998. PCR amplification of ribosomal DNA for species identification in the plant pathogen genus Phytophthora. Appl. Environ. Microbiol. 64:948-954.

33. Rizzo, D. M., Garbelotto, M., Davidson, J. M., Slaughter, G. W., and Koike, S. T. 2002. Phytophthora ramorum and sudden oak death in California: I. host relationships. U. S. Dep. Agric. For. Serv. Gen. Tech. Rep. PSW-GTR184:733-740.

34. Rizzo, D. M., Garbelotto, M., Davidson, J. M., Slaughter, G. W., and Koike, S. T. 2002. Phytophthora ramorum as the cause of extensive mortality of Quercus spp. and Lithocarpus densiflorus in California. Plant Dis. 86:205214.

35. Schlenzig, A. 2005. First report of Phytophthora inflata on nursery plants of Rhododendron spp., Gaultheria shalon and Vaccinium vitis-idaea in Scotland. Plant Pathol. 54:582.

36. Schwingle, B. W., Smith, J. A., and Blanchette, R. A. 2007. Phytophthora species associated with diseased woody ornamentals in Minnesota nurseries. Plant Dis. 91:97-102.

37. Schwingle, B. W., Smith, J. A., Blanchette, R. A., Gould, S., Blanchette, B. L. Blanchette, Pokorny, J., and Cohen, S. D. 2006. First report of dieback and leaf lesions on Rhododendron sp. caused by Phytophthora hedraiandra in the United States. Plant Dis. 90:109.

38. Shishkoff, N. 2006. Susceptibility of Camellia to Phytophthora ramorum. Plant Heath Progress doi: 10.1094/PHP-2006-0315-01-RS

39. Stamps, D. J., Waterhouse, G. M., Newhook, F. J., and Hall, G. S. 1990. Revised tabular key to the species of Phytophthora. CAB Int. Mycol. Inst. Mycol. Pap. 162

40. Testa, A., Schilb, M., Lehman, J. S., Cristinzio, G., and Bonnello, P. 2005. First report of Phytophthora insolita and P. inflata on rhododendron in Ohio. Plant Dis. 89:1128.

41. Tjosvold, S. A., Buermeyer, K. R., Blomquist, C., and Frankel, S. 2005. Nursery guide for diseases caused by Phytophthora ramorum on ornamentals: diagnosis and management. University of California Division of Agriculture and Natural Resources. Pub. 8156

42. Tooley, P. W., and Kyde, K. L. 2007. Susceptibility of some Eastern forest species to Phytophthora ramorum. Plant Dis. 91:435-438.

43. Tooley, P. W., Kyde, K. L., and Englander, L. 2004. Susceptibility of selected ericaceous ornamental host species to Phytophthora ramorum. Plant Dis. 88:993-999.

44. Tubajika, K. M., Bulluck, R., Shiel, P. J., Scott, S. E., and Sawyer, A. J. 2006. The occurrence of Phytophthora ramorum in nursery stock in California, Oregon, and Washington states. Online. Plant Heath Progress doi:10.1094/PHP-2006-0315-02-RS.

45. USDA Animal and Plant Health Inspection Service (APHIS). 2004. Emergency and Domestic Programs. Phytophthora ramorum. Program Updates. 26 July 2004. Published online.

46. USDA Animal and Plant Health Inspection Service (APHIS). 2004. Emergency and Domestic Programs. Phytophthora ramorum. Spotlights. 2004 Emergency and Federal Order. Rev. 21 December 2004. Published online.

47. USDA Animal and Plant Health Inspection Service (APHIS). 2005. Emergency and Domestic Programs. Phytophthora ramorum. Program Updates. 16 November 2005. Published online.

48. USDA Animal and Plant Health Inspection Service (APHIS). 2005. Emergency and Domestic Programs. Phytophthora ramorum. Protocols. Survey. Phytophthora ramorum 2006 National Nursery Survey, Survey Manual. Rev. 20 December 2005. Published online.

49. USDA Animal and Plant Health Inspection Service (APHIS). 2006. Emergency and Do- 
mestic Programs. Phytophthora ramorum. Spotlights. APHIS list of regulated hosts and plants associated with Phytophthora ramorum Rev. 11 September 2006. Published online.

50. USDA Animal and Plant Health Inspection Service (APHIS). 2007. Emergency and Domestic Programs. Phytophthora ramorum. Program Updates. December Report. 24 Janu- ary 2007. Published online.

51. Varela, P., Vásquez, J. P. M., and Casal, O. A. 2003. First report of Phytophthora ramorum on Camellia japonica in Spain. Plant Dis. $87: 1396$.

52. Werres, S., Marwitz, R., Man In't Veld, W. A., De Cock, A. W. A. M., Bonants, P. J. M., De Weerdt, M., Themann, K., Ilieva, E., and
Baayen, R. P. 2001. Phytophthora ramorum sp. nov., a new pathogen on Rhododendron and Viburnum. Mycol. Res. 105:1155-1165.

53. Žerjav, M., Munda, A., Lane, C. R., Barnes, A V., and Hughes, K. J. D. 2004. First report of Phytophthora ramorum on container-grown plants of rhododendron and viburnum in Slovenia. Plant Pathol. 53:523. 